\title{
The Main Factors Restricting ESP Teaching and the Countermeasures
}

\author{
Shengguang Yan ${ }^{1, a}$ Lijuan He ${ }^{2, b}$ Jinyang Zhang ${ }^{3, c}$ \\ ${ }^{1}$ International Education Center, North China University of Science and Technology, Tangshan, \\ Hebei, China, 063000 \\ 2 Kailuan General Hospital, Tangshan, Hebei, China, 063000 \\ ${ }^{3}$ Jeonju University, Jeonju, Korea, 55069 \\ ${ }^{a}$ email, ${ }^{b}$ email, ${ }^{\text {cemail, }}$
}

Keywords: Factors, Restrict, ESP Teaching, Countermeasures

\begin{abstract}
At present, Chinese college English ESP teaching is facing with many problems such as lacking of teachers, construction materials and other aspects of quality management. Therefore, in order to promote the optimal development of ESP teaching, the relevant departments should do the following aspects: strengthening the construction of ESP teaching quality assurance system, set up a special, independent university ESP faculty positions, the creation and improvement of the various disciplines of the ESP certificate examination system.
\end{abstract}

\section{Introduction}

In the late 70s of last century, China began to explore the University of ESP teaching, 1980s, ESP teaching have been good momentum of development, but due to lack of ESP teaching awareness, positioning is not clear, and lack of teacher qualifications problems, the teaching effect has been less than satisfactory. ESP teaching since the 1990s began to decline, which both awareness of the reasons, there are objective conditions, in the turn of the century, the increasingly frequent economic and social development and foreign exchange activities so that a new awareness of the ESP importance, in 1999 the newly revised "college English syllabus" to English as compulsory, university teaching ESP also won the rapid development, then the beginning of the new century decades, our academic university teaching ESP the main focus in what? This article analyzed and discussed from several aspects, mainly on the basis of a review of the relevant research results of domestic scholars to provide additional references for other related research, and lead people to pay more attention to our university ESP teaching.

With the development of social economy and science and technology, the importance of English has also been highlighted, in the context of English has been widely used all walks of life, not only a higher level of English, but also have a high professional quality of complex talent has been favored by society. This also requires the educational process, educators should pay attention to the teaching of English for Specific Purposes, namely ESP teaching, personnel training to ensure that the work to adapt and meet the needs of social development in improving students' ability on the basis of the composite.

\section{The Concept of ESP}

ESP (English for Specific Purposes) refers to the English for specific purposes, but also what we call English. It is a branch of English teaching, the general should have the following characteristics: 1) curriculum must meet the specific requirements of learners; 2) content with certain disciplines, occupations and activities; 3) emphasis should be placed on making grammar, vocabulary, discourse structure and those specific activities to be language use; 4) and EGP (English for General Purposes, public English) have significant differences. 


\section{The Current Situation of ESP Teaching}

Entry into the open and the Chinese need ESP cannot be questioned. But China is now the ESP teaching trough which was out of step with current needs. Some colleges and universities offer professional courses the ESP and some specialty original opened, and later canceled, fewer hours for less than 36 hours, up to 144 hours, most take larger classes. Almost all of the courses ESP courses are part-time teachers, teaching methods are simple, small number of achievements in scientific research, and more generally the course is introduced and the voice of experience. Except for a few areas (such as minority schools medical English), the ESP curriculum teaching effect is very satisfactory, the students "tend to ESP as a means of understanding of professional information, rather than the opportunity to continue to improve English language skills."

\section{The Constraints of ESP Teaching}

Teaching Goals of ESP Are Not Clear. In ESP teaching, although most students recognize the ESP teaching can help improve their level of English, but only a handful of students to recognize the significance of ESP to enhance their employability and help them solve business problems in the post, which species cognitive faculty is also widespread, this perception reflects the traditional English teaching and learning for teachers and students thinking thought formed in the present situation, but also reflects the awareness of teachers and teaching objectives of ESP misunderstanding. This ESP teaching goals are not clear problem easily lead to out of touch with social needs of students' abilities, and ESP English teaching is difficult to reflect the difference between ordinary English.

ESP Teaching Materials Are Scarce. Although there are currently many schools have launched ESP teaching, but the lack of teaching materials hampered ESP improve effectiveness. If requested by teachers to collect data from the primary preparation of teaching materials, teaching materials and has the consistency and systematic also be assured. At the same time, ESP informal teaching is difficult to ensure that the interest of students and teachers trust textbooks was mobilized. In addition, many skills appraisal standards and vocational qualification certificate does not attach importance to knowledge of English for specific purposes, therefore, teachers lack teaching materials to ESP dynamic development.

ESP Teaching Method Is Relatively Backward. Influenced by traditional English teaching mode in the current ESP teaching, there is still a large part of the teachers use the traditional lecture method to carry out teaching activities in this process, teachers' professional grammar and vocabulary to explain one by one, and students in learning the dominant position has not been adequate attention, which weakens ESP practicality and student motivation in ESP teaching to some extent. Therefore, ESP teaching process needs to focus on students' professional contact, while respecting the students to highlight the differences.

Lack Attention of Relevant Departments. since the reform and opening up, English attention, experts education administrative departments of the ESP recognized for college students with a certain sense, therefore, at the earliest, "College English Syllabus", in relation the basic stage into college English teaching and professional reading stages, initially offered courses to ESP EST (English for Science and Technology, Technical English) based. But because ESP itself interdisciplinary and socio-economic conditions at the time of the English language requirement is not high, experienced in the late 1980s to the early 1990s, after a brief technical English hot, almost stagnant development of ESP teaching, originally set up ESP professional school, because of its graduates no obvious advantage, had to give up its features.

Our ESP teaching would have started late, the lack of in-depth theoretical study, including the development of the original "College English Syllabus" of experts, including tertiary education who may not have carefully analyzed the nature of ESP, nor can it clear that in the end It is not English class. ESP courses for accurate positioning or not, not only determines its home, and determines its survival in China. Professional Teachers in both teaching and research, its main focus on their professional, ESP course is just their "sideline" only very limited effort spent on the above. This led 
directly to the ESP rigid teaching methods, teaching poor results, research stagnated. The English teachers ESP teaching and research interest is in teaching practice suffer no chance to even engage in scientific research, only on paper, you cannot link theory with practice.

\section{The Measures of ESP Teaching}

Set ESP Teaching Objectives Based on Teaching Demand. In ESP teaching, emphasis on teaching needs analysis, whether it is to improve ESP teaching objectives and social needs of adaptation, or ESP to improve the teaching process and the characteristics of students in terms of adaptability has important significance. Thus, in carrying out the ESP teaching process, to make the analysis of education needs should be the basic link. In this process, teachers need human capacity requirements made by society and the needs of students learning English to make research, research mainly includes the following aspects: First, professional information. This information is an important basis for determining the direction of ESP teaching; the second is the students, including students 'English literacy, learning experience, learning attitude, purpose, etc; the third is the lack of students' professional English. That contrast gap English proficiency requirements English level of students and society of the proposed personnel between. Play based on the content in ESP teaching objectives based on the determination, ESP teaching practical and should be sufficient as a starting point, combined with professional orientation school, teachers as well as students' professional needs to develop clear teaching objectives. Reasonable ESP teaching objectives should have an appropriate degree of difficulty and challenge, to avoid because it is too simple or too complex and consultations student learning initiative. While ESP teaching should attach importance to improve the English skills of the profession, such as for ESP teaching computer science undertaken should pay attention to students of English computer terminology knowledge, professional communicative competence and professional reading ability.

Strengthen the ESP Materials Development. ESP teaching with the advantage in improving students' professionalism aspects and get a lot of the school's attention, but the lack of ESP materials and also restricting the normal development and to improve the quality of teaching in these schools teaching, and therefore open ESP materials should be current ESP education one of the important tasks. In the ESP materials development process, it requires developed materials to reflect an association with the students professional and reflects the ease of learning, and reinforcement learning characteristics, but should pay attention to reflect the ESP's own characteristics and teaching characteristics and teaching law of ESP, thereby ensuring ESP school textbooks to meet the extensive professional education, adaptability, compatibility and usability requirements. In this regard, first, the development of ESP materials needed to make an analysis of the needs of the target, and ESP teaching has the particularity to be reflected and applied. This requires the teacher to the student's professional requirements, type of occupation and future job requirements to carry out research, and according to the students and the community need to determine the direction of ESP textbooks and details of the content; the second is ESP English textbooks need professional educational content combined. This not only requires teachers to be able to prepare English teaching according to the student curriculum materials, while to prepare English teaching according to students 'fields of expertise in some of the relevant knowledge, so as to reflect the ESP textbook emphasis on students' professional competence; Third ESP textbook degree of difficulty and students' English proficiency to adapt. ESP in the preparation of textbooks, not only to reflect the importance of teaching materials handling, as well as the need to have difficulty teaching hierarchy, so that the different levels of English students can improve their level of English for specific purposes by ESP materials. As to carry out vocational ESP teaching in colleges for poor students basic English case, it is necessary to add ESP teaching basic knowledge of English, and reduce the difficulty of English, thus avoiding the enthusiasm of students in learning would suffer; four ESP teaching is to reflect the characteristics of the times. As students of professional expertise with the development of the theory of constantly updated, and ESP order to reflect the adaptability of expertise, it should have the characteristics of the times.

Make Reform of ESP Teaching Methods. In ESP teaching, teaching methods make the reform 
will help improve the quality and efficiency of teaching ESP. In ESP teaching, a lot of good teaching methods can be applied, such as cooperative learning teaching, task-driven teaching and different levels of teaching. While improving students' professional capacity as the starting point of view, in carrying out the ESP teaching activities, to emphasize combined ESP and practical teaching and online teaching. Since the practice of teaching to allow students to experience real working environment to make students apply their knowledge in the use of their own can be done on the basis of theoretical knowledge, so the combination of ESP and practical teaching, help improve students' English proficiency, and stimulate students' motivation and interest in learning. So, in ESP teaching, teachers should not only pay attention to ESP teaching content and expertise in contact, at the same time pay attention to the teaching activities extend ESP Practice Teaching. With this implementation of teaching methods, students can more clearly recognize the ESP knowledge needed to work in, and able to carry out targeted learning in ESP teaching, which improve the quality and efficiency of ESP teaching purposes It has important significance. In connection with the aspects ESP teaching and online teaching, because the network is not only conducive to promoting teaching students to gain a richer learning materials, and help students to engage in independent study. In addition, the network has knowledge of the fast update rate, importance to achieving ESP combining teaching and online teaching, help solve the ESP classroom teaching content updates lagging behind the problem, so that students master the knowledge of ESP can have the characteristics of the times. So pay attention with the network teaching in ESP teaching allows students according to their level of English, the ability to accept and to learn the characteristics of their own to improve the knowledge of English for specific purposes, so this can be used as a means of teaching ESP classroom activities an important supplement. In teaching the use of such means to carry out the process of ESP teaching, the school should pay attention to the development and use of its campus network resources, through the improvement of multimedia classrooms and electronic libraries and other venues and facilities to allow students to easily use the internet terminals to carry out the ESP learning, so that students have a richer ESP learning channels.

\section{Conclusion}

With the development of social economy and science and technology, the importance of English has also been highlighted, in the context of English has been widely used all walks of life, not only a higher level of English, but also have a high professional quality compound talents have been favored by the society, which also requires the educational process, educators should pay attention to the teaching of English for Specific purposes, namely ESP teaching, so as to ensure the work of personnel training to enhance students' ability on the basis of the composite can adapt and meet the social development needs.

\section{References}

[1] Jia Xinzhang, Li Jingyuan. China Adult Education, Vol. 6 (2014) No 53, p.25-26

[2] Peng Sue, Wang Yunhui. Chinese School Education, Vol. 12 (2015) No 27, p.74-76

[3] Jing Jianfen, Hou XuSiem. Chinese School Education, Vol. 30 (2014) No 19, p.144-145

[4] Wang Kuailiang. Vocational and Technical Education, Vol. 29 (2008) No 27, p.21-23

[5] Sun Jing. Foreign Language Teaching and Research, Vol. 8 (2013) No 27, p.57-60 